\title{
Muḥa u Ḥemmu Aẓayyi
}

cf. Moha-ou-Hammou Zaïani, M124

\section{OpenEdition}

\section{Journals}

Édition électronique

URL : https://journals.openedition.org/encyclopedieberbere/647

DOI : 10.4000/encyclopedieberbere.647

ISSN : 2262-7197

Éditeur

Peeters Publishers

Édition imprimée

Date de publication : 31 décembre 2010

Pagination : 5101

ISBN : 978-90-429-2369-0

ISSN : 1015-7344

\section{Référence électronique}

"Muha u Hemmu Azayyi », Encyclopédie berbère [En ligne], 32 | 2010, document M00, mis en ligne

le 31 décembre 2015, consulté le 17 février 2022. URL : http://journals.openedition.org/

encyclopedieberbere/647; DOI : https://doi.org/10.4000/encyclopedieberbere.647

Ce document a été généré automatiquement le 17 février 2022.

(c) Tous droits réservés 


\section{Muḥa u Ḥemmu Aẓayyi}

Cf. Moha-ou-Hammou Zaïani, M124

Cf. Moha-ou-Hammou Zaïani, M124 